\title{
PENINGKATAN KEMAMPUAN BERPIKIR KREATIF MELALUI LEMBAR KERJA PESERTA DIDIK (LKPD) BERBASIS CREATIVE PROBLEM SOLVING
}

\author{
Nurlaely Sabaniah $^{1 *}$, Endang Widi Winarni ${ }^{1}$, Dewi Jumiarni ${ }^{1}$ \\ ${ }^{1}$ Program Studi Pendidikan Biologi, Fakultas Keguruan Dan Ilmu Pendidikan, Universitas Bengkulu \\ Email: nurlaelysabaniah@gmail.com
}

\begin{abstract}
Abstrak
Penelitian ini bertujuan untuk meningkatkan kemampuan berpikir kreatif peserta didik kelas X SMA melalui LKPD Biologi berbasis creative problem solving pada materi pencemaran lingkungan. Jenis penelitian ini adalah penelitian dan pengembangan. Metode penelitian mengadopsi model penelitian desain Borg and Gall dengan4 tahapan. Subjek penelitian adalah 27 orang peserta didik kelas X MIPA 3 SMA Negeri 1 Bengkulu Tengah. Terdapat 2 variabel yaitu variabel bebas adalah LKPD berbasis creative problem solving, dan variabel terikat adalah kemampuan berpikir kreatif. Instrument yang digunakan untuk mengukur kemampuan berpikir kreatif berupa tes tertulis. Hasil penilaian validasi keseluruhan aspek bahan ajar LKPD yang dikembangkan memiliki kelayakan sangat baik dengan persentase $89,50 \%$. Hasil posttest peserta didik setelah belajar menggunakan semua LKPD menunjukkan keberhasilan ditunjukkan oleh nilai rata-rata yaitu 81,25 dan telah mencapai KKM, dan perolehan ketuntasan kelas sebesar $85,18 \%$. Dapat disimpulkan bahwa LKPD biologi berbasis creative problem solving layak dan efektif untuk digunakan pada pembelajaran di kelas X SMA.
\end{abstract}

Kata Kunci: LKPD, berpikir kreatif, creative problem solving.

\begin{abstract}
This study aimed to develop Biological students worksheet based on creative problem solving towards enviromental pollution topic to improve the creative thinking ability of the students grade $\mathrm{X}$ in senior high school. The design of this research was research and development. This research method by adopting the Dick and Carey model consisting of 8 stages, then it will be tested for its feasibility and effectiveness using R\&D design research according to (Borg and Gall, 1998) which consists of 4 stages. Subjects of this research were 27 students in class $X$ SMAN 1 Bengkulu City. There are 2 Variabels, namely the independent variabel is the worksheet based on creative problem solving and the dependent variabel is the ability to think creatively. Instrument used to measure the ability to think creatively was in the form of written test. The results of validation assesment on all aspects of teaching material in biology students worksheet was highly feasible with a percentage of $89,5 \%$. The result of postest of the students' creatively thinking ability by applied to use all biological student worksheet showed by the average value of student learning outcomes is 81,25 and has reached Minimum Mastery Criteria, and the acquisition of class completeness was $85,18 \%$. From the results of the study, it was concluded that the worksheet of biology students were based on creative problem solving that was feasible and effective to be used in biology learning in class $\mathrm{X}$ high school.
\end{abstract}

Keyword :Students worksheet, problem solving, creative problem solving 


\section{PENDAHULUAN}

Pada era globalisasi abad 21 ini, persaingan begitu ketat dari berbagai macam bidang, yaitu salah satunya adalah bidang pendidikan. Hal ini dikarenakan individu yang kreatif memiliki kepercayaan diri, mandiri, tanggung jawab dan komitmen pada tugas, tidak kehabisan akal dalam berpikir kreatif, dan kaya inisiatif. Tujuan tersebut sesaui dengan tujuan Pendidikan Nasional yaitu mengembangkan potensi peserta didik agar menjadi manusia kreatif.

Keterampilan berpikir kreatif adalah suatu proses berpikir yang digunakan individu untuk menghasilkan gagasan yang baru, atau mengembangkan gagasan orang lain dalam memecahkan suatu masalah. Manusia yang kreatif diyakini mampu berkompetisi di era globalisasi, karena mereka dapat memberikan kontribusi yang positif dalam berbagai bidang, seperti bidang sosial, ekonomi, dan teknologi (Maisaroh, 2018).

Berdasarkan hasil observasi dan wawancara, guru bidang studi Biologi mengungkapkan bahwa bahwa kemampuan berpikir kreatif peserta didik kelas $X$ di SMAN Bengkulu Tengah masih rendah. Keadaan ini dilihat dari ketidakmampuan siswa dalam memecahkan masalah secara efektif. Faktor yang dapat menyebabkan hal tersebut yaitu 1) bahan ajar berupa LKPD yang digunakan dalam pembelajaran belum menyisipkan fakta dan fenomena yang memberikan kesempatan pada peserta didik untuk melakukan kegiatan penyelidikan dan pemecahan masalah yang dapat melatih peserta didik untuk berpikir kreatif secara kreatif, guna meningkatkan kemampuan berfikir kreatif peserta didik. 2) kurangnya pemanfaatan lingkungan sebagai sumber belajar. Padahal lingkungan dapat memperkaya wawasan dan pengetahuan. Sehingga pengetahuan yang diperoleh lebih akurat, sebab peserta didik mengalami secara langsung, mencari masalah yang ada di lingkungannya lalu berpikir kreatif tersebut.

Salah satu permasalahan yang terdapat di sekitar yaitu tentang limbah. Keberadaan limbah ditunjukan dengan adanya bahan fisik air sungai aliran dari pabrik karet yang berada dekat dengan lingkungan sekolah. Adanya limbah mengakibatkan air sengai menjadi tercemar. Hasil observasi menemukan bahwa tumpukan sampah terletak di pinggiran sungai.

Upaya yang dapat dilakukan untuk mengatasi permasalahan pembelajaran tersebut yaitu menerapkan inovasi bahan ajar yang dapat meningkatkan keterampilan berpikir kreatif peserta didik. Pengembangan bahanajaryang memiliki karakteristik dan kebutuhan peserta didik berupa LKPD berbasis creative problem solving yang menggunakan kurikulum 2013 sesuai dengan Kompetensi Inti (KI) dan Kompetensi Dasar (KD) yang dicapai yaitu 3.11 Menganalisis data perubahan lingkungan, penyebab, dan dampaknya bagi kehidupan dan 4.11 Merumuskan gagasan pemecahan masalah perubahan lingkungan yang terjadi di lingkungan sekitar (Permendikbud Nomor 24 tahun 2016).

Materi pelajaran biologi yang diangkat dalam LKPD adalah "Dampak Pencemaran Lingkungan". LKPD tersebut melatih peserta didik untuk memahami materi pencemaran lingkungan dan melatih kemampuan berpikir kreatif. Sehingga LKPD berfungsi untuk memicu dan membantu peserta didik melakukan kegiatan belajar agar dapat menguasai suatu pemahaman, keterampilan, dan sikap. Selain itu untuk membantu mengarahkan pembelajaran sehingga lebih efektif dan efisien.

Agar pembelajaran dapat berjalan lebih efektif maka digunakan LKPD yang disusun berdasarkan langkah- langkah pembelajaran dengan model Creative Problem Solving. Menurut Winarni (2018:179) yaitu 1). Penemuan fakta, 2). Penemuan masalah, berdasarkan fakta-fakta yang telah dihimpun, 
ditentukan masalah/pertanyaan kreatif untuk dipecahkan, 3). Penemuan gagasan, menjaring sebanyak mungkin alternatif jawaban untuk berpikir kreatif, 4). Penemuan jawaban, penentuan tolak ukur atas kriteria pengujian jawaban yang diharapkan, 5). Penentuan penerimaan, ditemukan kebaikan dan kelemahan gagasan, kemudian menyimpulkan dari masing-masing masalah yang dibahas.

Penelitian ini bertujuan untuk mengetahui kelayakan LKPD Biologi berbasis creative problem solving dan mengetahui efektifitas LKPD Biologi pada materi pencemaran lingkungan untuk meningkatkan kemampuan berpikir kreatif peserta didik kelas $X \mathrm{MIPA}_{3}$ SMAN 1 Bengkulu Tengah setelah belajar dengan menggunakan LKPD Biologi berbasis creative problem solving.

\section{METODE}

Jenis penelitian yang dilakukan adalah penelitian dan pengembangan (Research and Development) yang terdapat 10 langkah pokok dalam penelitian dan pengembangan namun pada penelitian pengembangan ini sesuai dengan tujuan penelitian maka pada pengembangan ini hanya sampai langkah ke 4 dengan menitik beratkan pada langkah-langkah yaitu :1) Research and information collecting, 2) Planning, 3) Develop preliminary form of product, dan 4) Preliminary field testing.

Subjek Penelitian adalah peserta didik kelas X MIPA 3 SMA Negeri 1 Bengkulu Tengah berjumlah 27 orang peserta didik. Instrumen yang digunakan untuk mengukur kemampuan berpikir kreatif berupa tes tertulis. Instrumen untuk mengetahui kevalidan LKPD yang telah dikembangkan peneliti adalah lembar angket validasi dan uji keterbacaan. Penilaian validasi meliputi aspek kelayakan isi, kebahasaan, penyajian dan kegrafikan (Depdiknas, 2008). Validasi LKPD dilakukan oleh tiga Dosen ahli yaitu 1 ahli media, 1 ahli materi dan 1 ahli ilmu pendidikan biologi dan dua praktisi (Guru
Biologi) serta uji keterbacaan dilakukan oleh peserta didik kelas X MIPA 3 SMA N 1 Bengkulu Tengah berjumlah 27 Orang. Analisis hasil penilaian validasi dilakukan dengan menghitung skor rata-rata dari setiap aspek dengan menggunakan rumus sebagai berikut :

Presentase $=\frac{\text { Jumlah skor lembar validasi }}{\text { Skor maksimal }} \times 100 \%$
Riduwan $(2015: 15)$

Data yang diperoleh dikonversi menjadi nilai dengan kriteria sesuai dengan Tabel 1.

Tabel 1. Kriteria Interpretasi Skor Uji Validitas

\begin{tabular}{ll}
\hline Persentase & Kriteria \\
\hline $0 \%-20 \%$ & Sangat Tidak Valid \\
$21 \%-40 \%$ & Tidak Valid \\
$41 \%-60 \%$ & Cukup Valid \\
$61 \%-80 \%$ & Valid \\
$81 \%-100 \%$ & Sangat Valid \\
\hline
\end{tabular}

Data hasil pengukuran untuk mengetahui keefektifitasan LKPD Biologi menggunakan (soal postest) dianalisis dengan menggunakan rumus

$\% \mathrm{~KB}=\frac{n}{N} x 100 \%$

Sugiyono (2008)

Keterangan :

$\mathrm{KB}=$ ketuntasan belajar secara klasikal

$\mathrm{n} \quad$ = jumlah siswa yang mendapatkan nilai di atas $\mathrm{KKM} \geq 76$

$\mathrm{N}=$ jumlah seluruh peserta didik Ketuntasan belajar secara klasikal tercapai jika $\geq 80 \%$

Data hasil pengukuran kemampuan berpikir kreatif peserta didik baik secara kelompok (LKPD berbasis creative problem solving) maupun individu (soal postest) dianalisis dengan menggunakan rumus:

$$
\text { Nilai }=\frac{\text { Skor mentah }}{\text { Skor maksimal }} \times 100 \%
$$


Data yang dianalisis selanjutnya dikonversikan dengan menggunakan kriteria pada Tabel 2 berikut:

Tabel 2. Interval dan Kategori Konversi Keterampilan Berpikir Kreatif Peserta Didik

\begin{tabular}{ll}
\hline Interval & Kategori \\
\hline $94-100$ & Sangat Baik \\
$88-93$ & Baik \\
$82-87$ & Cukup \\
$<81$ & Kurang \\
\hline & (Kemendikbud,2015)
\end{tabular}

\section{HASIL DAN PEMBAHASAN}

Berdasarkan hasil analisis data angket validasi LKPD Biologi berbasis creative problem solving yang telah dilakukan uji validasi oleh tiga dosen ahli yaitu ahli media, ahli materi dan ahli ilmu pendidikan biologi UNIB, serta dua orang guru SMA Negeri 1 Bengkulu Tengah. Rekapitulasi hasil validasi skor rata-rata dan persentase keidealan pada tiap aspek dari tim validator pada LKPD 1 dan 2 disajikan pada Tabel 3.

Hasil analisis data angket validasi menunjukkan bahwa tiap aspek yang dinilai tim dosen dan guru menunjukkan skor rata-rata keseluruhan yaitu 81,12 persentase keidealan $84,5 \%$ dengan kategori sangat baik. Sehingga dinyatakan bahwa LKPD yang dikembangkan layak untuk di uji cobakan. Hal ini sesuai dengan pernyataan Widjajanti (2013) yaitu LKPD yang disusun secara sistematis, rapi, dan mudah di pahami oleh peserta didik memiliki fungsi sebagai alternatif bagi guru untuk mengarahkan pengajaran, membantu peserta didik untuk lebih aktif dalam proses pembelajaran, meningkatkan motivasi belajar dan rasa ingin tahu dan mempermudah penyelesaian tugas perorangan ataupun kelompok.
Tabel 3. Rekapitulasi Hasil validasi LKPD 1 dan 2 oleh Tim Validator

\begin{tabular}{cccc}
\hline $\begin{array}{c}\text { Aspek } \\
\text { Penilaian }\end{array}$ & $\begin{array}{c}\text { Skor rata- } \\
\text { rata } \\
\text { Keseluruhan }\end{array}$ & $\begin{array}{c}\text { Persentase } \\
\text { keidealan }\end{array}$ & Kategori \\
\hline Isi & 41.38 & 86,2 & Sangat baik \\
Kebahasaan & 12.12 & 75,75 & Baik \\
Penyajian & 10 & 83,33 & Sangat baik \\
Kegrafikan & 17,62 & 88,1 & Sangat baik \\
Skor & 81,12 & 84,5 & Sangat baik \\
keseluruhan & & & \\
aspek & & & \\
\hline
\end{tabular}

Dari hasil validasi oleh tim validator terdapat beberapa bagian dari LKPD yang perlu direvisi. Adapun bagian LKPD sebelum dan sesudah revisi yaitu pada Tabel 4. 
Tabel 4. Perbedaan LKPD Sebelum Revisi dan Sesudah Revisi

\begin{tabular}{|c|c|c|c|}
\hline NO & LKPD Sebelum revisi & LKPD setelah revisi & Keterangan \\
\hline 1 & GoOD Luck at: & 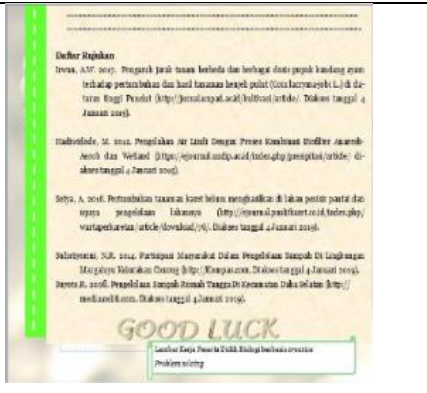 & $\begin{array}{l}\text { Pada LKPD sebelum revisi } \\
\text { tidak terdapat daftar } \\
\text { rujukan/ daftar pustaka }\end{array}$ \\
\hline 2 & 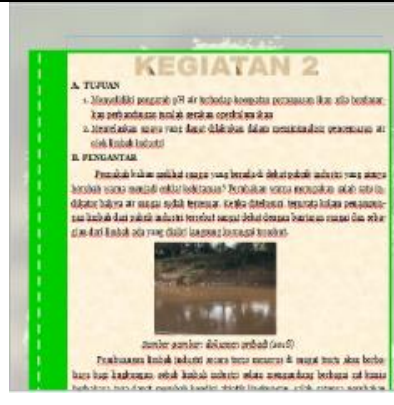 & 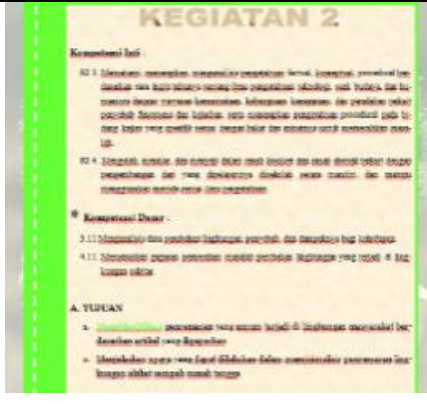 & $\begin{array}{l}\text { Pada LKPD sebelumrevisi } \\
\text { tidak terdapat } \\
\text { kompetensi dasar dan } \\
\text { kompetensi inti hanya } \\
\text { terdapat tujuan }\end{array}$ \\
\hline 3 & 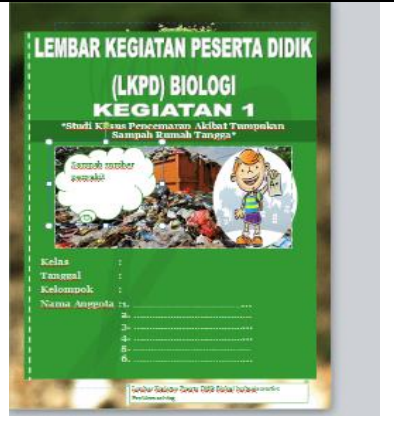 & 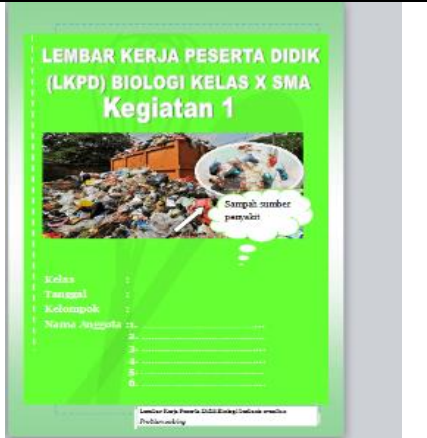 & $\begin{array}{l}\text { Pada LKPD sebelum revisi } \\
\text { warna cover/ halaman } \\
\text { depan LKPD terlalu gelap } \\
\text { dan gambar yang } \\
\text { mendukung terlalu penuh } \\
\text { dan tidak efisien. }\end{array}$ \\
\hline
\end{tabular}


Pada penelitian ini juga dilakukan pengukuran kemampuan berpikir kreatif peserta didik yang terdiri dari 2 aspek, yaitu pengukuran kemampuan berpikir kreatif yang dilihat dari skor kinerja kelompok aspek kognitif dengan menggunakan LKPD Biologi berbasis creative problem solving materi pencemaran lingkungan yang dikembangkan oleh peneliti dan kemampuan berpikir kreatif dilihat dari skor postest aspek kognitif peserta didik secara individu. Adapun hasil analisis data kinerja kelompok menggunakan LKPD Biologi berbasis creative problem solving di sajikan pada Tabel 5.

Jika dilihat dari Tabel 5, kemampuan berpikir kreatif peserta didik tertinggi berada pada dimensi berpikir lancar. Tingginya nilai yang dicapai peserta didik terutama pada dimensi berpikir lancar tersebut tentu tidak terlepas dari LKPD yang dikembangkan berdasarkan creative problem solving yaitu permasalahan yang di sajikan pada LKPD merupakan masalah yang umum terjadi di lingkungan peserta didik dan sesuai dengan fakta sehingga peserta didik mampu mengemukakan gagasannya dengan baik. Hal ini sesuai dengan Guilford; Stenberg \& kauffman, (2010) yang menyatakan bahwa kelancaran (fluency, yaitu kesiagapan, kelancaran, kemampuan untuk menghasilkan banyak gagasan secara cepat, dalam kelancaran berpikir, yang di tekankan adalah kuantitas dan bukan kualitas.

Tabel 5. Rekapitulasi Hasil Pengukuran Kemampuan Berpikir Kreatif Peserta Didik Secara Kelompok

\begin{tabular}{llll}
\hline NO Aspek Yang Diamati & \multicolumn{2}{l}{ Nilai rata-rata } & Kriteria \\
\hline $\begin{array}{l}1 \\
\text { Baik }\end{array}$ & Berpikir Lancar & $92 \%$ & Sangat \\
2 & Berpikir Luwes & $83,3 \%$ & Cukup \\
3 & Berpikir Orisinil & $82,5 \%$ & Cukup \\
4 & Berpikir Elaboration & $80 \%$ & Kurang \\
5 & Perumusan Kembali & $78,3 \%$ & Kurang \\
& Rata-rata 83,22 \% Cukup & \\
\hline
\end{tabular}

Keterangan : *kriteria berdasarkan (Modifikasi Kemendikbud,2015)

Adapun hasil analisis data dari postest kemampuan berpikir kreatif dapat dilihat pada Tabel 5. Perolehan nilai rata-rata postest berpikir kreatif tersebut di ambil dari hasil penilaian setiap dimensi berpikir kreatif. Adapun hasil nilai hasil postest kemampuan berpikir kreatif peserta didik secara individu Berdasarkan Tabel 6 diatas dapat dilihat bahwa pada dimensi kelancaran nilai yang diperoleh paling tinggidibandingkan dengan dimensi lain, perolehan nilai tertinggi pada dimensi ini karena siswa tersebut diberikan stimulus berupa fakta suatu persoalan yang ada di lingkungan sekitar peserta didik, kemudian siswa di tuntut untuk menjawab dengan banyak gagasan. Dikatakan level kelancaran karena jawaban permasalahan tersedia berupa fakta-fakta yang di sajikan. Pada dimensi keluwesan siswa di tuntut untuk memberikan argument tentang sebab dan akibat dari suatu permasalahan, pada dimensi ini siswa diberikan stimulus berupa pertanyaan yang dapat memancing siswa untuk memberikan argument yang berhubungan dengan kelancaran, sehingga jika peserta didik sudah menguasai dimensi kelancaran maka peserta didik akan lebih mudah dan lancar untuk memberikan argumen tentang suatu persoalan, pada dimensi ini siswa dituntut untuk mengambil keputusan yang fleksibel terhadap permasalahan yang ada.

Pada dimensi berikutnya yaitu dimensi keaslian, pada dimensi ini peserta didik dituntut untuk memberikan keaslian gagasan pada suatu permasalahan yaitu dengan cara memberikan sejumlah gagasan baru yang berbeda dengan yang sudah ada. Dimensi ke empat yaitu dimensi penguraian, pada dimensi ini siswa di tuntut untuk dapat menguraikan sesuatu gagasan secara detail. 
Tabel 6. Rekapitulasi Nilai Posttest Kemampuan Berpikir Kreatif Peserta Didik Secara Individu

\begin{tabular}{llcl}
\hline $\begin{array}{c}\text { No Aspek Yang } \\
\text { Diamati }\end{array}$ & Persentase & Kriteria \\
\hline 1 & Kelancaran & $89,8 \%$ & Baik \\
2 & Keluwesan & $84,16 \%$ & Cukup \\
3 & Keaslian & $84 \%$ & Cukup \\
4 & Elaboration & $83,4 \%$ & Cukup \\
5 & Perumusan & $71,6 \%$ & Kurang \\
\multicolumn{3}{c}{ Kembali } & Rata-rata 82,59 \\
\hline Keterangan: & (Modifikasi \\
*kriteria &
\end{tabular}

Memecahkan masalah secara kreatif secara kompleks. Dari hasil postest yang didapat, selanjutnya akan diketahui hasil belajar peserta didik berdasarkan postest 1 dan 2 yang akan di sajikan pada Tabel 7 .

Tabel 7. Rekapitulasi Hasil Belajar Peserta Didik Berdasarkan Postest 1 dan 2

\begin{tabular}{lll}
\hline Kegiatan & $\begin{array}{l}\text { Skor } \\
\text { Perolehan }\end{array}$ & Keterangan \\
\hline Kegiatan 1 & 77,51 & Tuntas \\
Kegiatan 2 & 85 & Tuntas \\
Rata-rata & 81,25 & \\
Ketuntasan & 85,18 & Tuntas \\
Klasikal & & \\
\hline
\end{tabular}

Berdasarkan Tabel adanya

keberhasilan dalam pembelajaran biologi setelah menggunakan LKPD biologi berbasis creative problem solving pada materi pencemaran lingkungan. Dimana pada proses pembelajaran siswa di hadapkan pada masalah nyata yang ada di lingkungan sekitar peserta didik dan peserta didik dituntut untuk mampu memecahkan masalah secara kreatif. Hal ini sesuai dengan pendapat Alfi, dkk (2016) bahwa pembelajaran akan lebih efektif apabila memberikan kesempatan kepada siswa untuk berpikir aktif yang mampu mendorong siswa untuk membangun pengetahuan mereka sendiri. Salah satu komponen yang menunjang upaya peningkatan kemampuan berpikir kreatif siswa melalui pembelajaran yaitu penggunaan bahan ajar yang disesuaikan dengan karakteristik dan kebutuhan siswa. LKPD yang mengakomodasi kemampuan berpikir kreatif yaitu LKPD yang didukung dengan penggunaan model pembelajaran yang tepat sehingga mampu membuat peserta didik belajar dengan efektif. Munandar (2003) menjelaskan bahwa perkembangan optimal dari kemampuanberpikir kreatif berhubungan erat dengancara mengajar. Pehkonen (1997) berpendapat bahwa cara untuk meningkatkan berpikir kreatif dan keterampilan generik melalui pendekatan pemecahan masalah dengan kemampuan berpikir kreatif. Menurut teori perkembangan kognitif Piaget, peserta didik kelas $X$ SMA/MA yang berumur antara 14-15 tahun yang termasuk dalam tahap berpikir operasi formal, peserta didik mulai bergelut dengan konsep yang ada di luar pengalaman mereka sendiri, lalu masalah-masalah dapat di pecahkan melalui penggunaan eksperimentasi sistematis (Trianto, 2014).

Penelitian yang pernah dilakukan oleh Swestiyani, dkk (2014) tentang Pengembangan bahan ajar berupa Modul IPA berbasis creative problem solving untuk meningkatkan kemampuan berpikir kreatif siswa menunjukkan bahwa modul IPA tersebut memiliki efektifitas tinggi karena model Creative problem solving ini menekankan pada keterampilan memecahkan masalah untuk memilih dan mengembangkan tanggapannya. Tidak hanya dengan cara menghafal tanpa difikir keterampilan memecahkan masalah memperluas proses berpikir kreatif.

Adapun keunggulan dari LKPD yang dikembangkan sehingga dapat meningkatkan kemampuan berpikir kreatif peserta didik yaitu LKPD yang dirancang berbasis creative problem solving yang merupakan bagian dari model Problem based learning dimana menurut Trianto (2014), berdasarkan pendapat Arends pada dasarnya problem based learning 
mengorientasi peserta didik pada masalah autentik dan menghindari dari pembelajaran terisolasi, masalah diformulasikan untuk memfokuskan dan merangsang pembelajaran sehingga dapat mengajarkan kepada peserta didik untuk mampu menerapkan apa yang mereka pelajari di sekolah dalam kehidupannya, hal ini sesuai dengan pernyataan dari Setiawati (2018) yang menyatakan bahwa persoalan yang disajikan dalam LKPD menghadirkan situasi yang konkrit ke dalam pembelajaran yang mengharuskan peserta didik untuk memahami persoalan yang kompleks agar peserta didik terdorong untuk memahami ilmu yang telah dipelajarinya, kemudian dapat menerapkan ilmu tersebut dengan permasalahan yang terjadi di lingkungan sekitarnya seperti hubungan antara pencemaran lingkungan dan dampaknya. LKPD yang dikembangkan menyajikan permasalahan yang umum terjadi di lingkungan peserta didik sehingga peserta didik lebih dapat memahami dan lebih mudah untuk memecahkan permasalahan yang terdapat dalam LKPD dan pembelajaran yang berorientasi pada kearifan lokal diyakini mampu meningkatkan keterampilan penyelesaian masalah karena pembelajaran yang disampaikan sesuai dengan keadaan yang ada di lingkungan hal ini sesuai dengan Khotimah (2018), yang menyatakan bahwa pembelajaran yang berorientasi pada kearifan lokal lebih memberikan kesan yang kontekstual dalam pembelajaran sehingga siswa mudah memahami materi yang dipelajari. Sesuai pendapat Sanjaya (2006) bahwa pembelajaran dengan creativeproblem solving mempunyai keuntungan positif bagi perkembangann peserta didik yaitu bagaimana mentrasfer pengetahuan mereka untuk memahami masalah dalam kehidupan nyata.

LKPD yang dikembangkan di susun berdarkan panduan dari depdiknas (2008) dan dalam segi penyajian LKPD yang dikembangkan lebih menarik dari segi warna dan gambar lebih jelas.

\section{PENUTUP \\ Simpulan}

Lembar kerja peserta didik (LKPD) hasil pengembangan dinyatakan layak untuk diuji cobakan kepada peserta didik oleh tim dosen ahli dan praktisi karena memberikan hasil 89,5\% dengan kategori sangat baik. Dan pembelajaran dengan menggunakan LKPD biologi hasil pengembangan berbasis creative problem solving dapat meningkatkan kemampuan berpikir kreatif peserta didik, hal ini dapat dilihat dari rata-rata skor perolehan secara hasil kinerja peserta didik secara kelompok setelah dilakukan uji coba LKPD kegiatan 1 dan 2 yaitu 83,22\%, dan rata-rata skor kemampuan berpikir kreatif peserta didik secara individu yaitu $82,59 \%$.

\section{Saran}

Berdasarkan hasil penelitian yang telah dilakukan maka peneliti lanjutan agar dapat melakukan pengembangan terhadap dimensi kemampuan berpikir kreatif dengan cara mengembangakan indikator-indikator yang lebih tinggi dan berbeda namun disesuaikan dengan tingkat perkembangan peserta didik. Dan perlu dilakukan uji coba dengan skala yang lebih luas melibatkan sampel siswa dan sekolah yang lebih banyak untuk melihat efektifitas LKPD yang dikembangkan.

\section{DAFTAR PUSTAKA}

Alfi, dkk. (2016). Pengaruh Pembelajaran Geografi Berbasis Masalah Dengan Blended Learning Terhadap Kemampuan Berpikir Kritis Siswa SMA. Jurnal Pendidikan,1(4):67-68. (online)

(http://jurnal.unsyiah.ac.id.pdf). Diakses tanggal 2 Februari 2019 
Depdiknas. (2008). Panduan Pengembangan Bahan Ajar SMA/MA. Jakarta: Depdiknas

Kauffman, J.C., Stenberg, R.J. (2010). The Cambridge Handbook of Creativity. Cambridge: Cambridge University Press

Khotimah, dkk. (2018). Pengantar Analisis Real. Surakarta: Muhammadiyah University Press

Maisaroh, Noor. F., \& Chansyanah, D. (2018). Efektivitas Pembelajaran Berbasis Masalah Pencemaran oleh Limbah Detergen. Jurnal Pendidikan, 3(1): 8-11. (online) (http://Pasca.undiksha.ac.id/ejour nal/index.php/jurnalpendidikan /article/view/135). Diakses tanggal 10 November 2018

Munandar, S. C., \& Utami. (2003). Kreativitas dan Keberbakatan. Strategi Mewujudkan potensi kreatif dan Bakat. Jakarta: PT Gramedia Pustaka Utama

Pehkonen, E. (1997). The State-of-Art in Mathematical Creativity. ZDM 29 (3). Electronic Edition ISSN 1615679X.(online) (http;//link.springer.cpm/article/). Diakses tanggal 12 Februari 2019

Permendikbud Nomor 24 Tahun 2016 Tentang Kompetensi Inti dan Kompetensi Dasar Kurikulum 2013 pada Pendidikan Dasar dan Menengah.

Setiawati, P. N. (2018). Pengembangan LKPD IPA Berbasis Service Learning Untuk Meningkatkan Kemampuan Feflective Thinking Siswa. Jurnal Diklabio 2 (1): 76-85. (online) (https://ejournal.unib.ac.id/ind ex.php/jppb/article/view/5145/27 04). Diakses pada tanggal 1 Juli 2019
Riduwan. (2015). Skala Pengukuran Variabel-variabel Penelitian. Bandung: Alfabeta.

Sanjaya, W. (2006). Strategi Pembelajaran Berorientasi Standar Proses Pendidikan. Jakarta: Kencana

Sugiyono. (2008). Metode Penelitian Pendidikan (Pendekatan Kuantitatif, Kualitatif, dan R\&D). Bandung: Alfabeta.

Surna, I. N., Panderiot., \& Olga, D. (2013). Psikologi Pendidikan 1. Jakarta: Erlangga

Swestyani, dkk. (2014). Pengembangan Modul IPA Berbasis Creative Problem Solving (CPS) Untuk Meningkatkan Kemampuan Berpikir Kreatif Siswa. Jurnal Pembelajaran Biologi,6(2): 3738. (online) (https://media.neliti.com). Diakses tanggal 5 November 2018

Trianto. (2014). Mendesain Model Pembelajaran Inovatif, Progresif Kontekstual. Jakarta: Prestasi Pustaka Publisher

Undang-undang Nomor 20 Tahun 2003. Tentang Sistem Pendidikan Nasional. Jakarta : Bidang Dikbud KBRI Tokyo

Widjajanti, E. (2013). Kualitas Lembar Kerja Siswa. Jurnal Wahana Pendidikan Kimia, 2(1): 45-46. (online) (http://jurnal.fkip.unila.ac.id). Diakses tanggal 5 November 2018

Winarni, E. W. (2018). Pendekatan IImiah Dalam Pembelajaran Inovatif dan Kreatif. Bengkulu : FKIP UNIB 